$7-2020$

\title{
Association of circulatory kisspeptin levels and hormonal interplay with male infertility: A cross-sectional study in Karachi, Pakistan
}

Rehana Rehman

Kaleem Ahmed

Nida Zahid

Faiza Alam

Syeda Sadia Fatima

Follow this and additional works at: https://ecommons.aku.edu/pakistan_fhs_mc_bbs

Part of the Life Sciences Commons, Male Urogenital Diseases Commons, and the Surgery Commons 


\title{
Association of circulatory Kisspeptin levels and hormonal interplay with male infertility: A cross-sectional study in Karachi, Pakistan
}

Rehana Rehman, ${ }^{1}$ Kaleem Ahmed, ${ }^{2}$ Nida Zahid, ${ }^{3}$ Faiza Alam, ${ }^{4}$ Syeda Sadia Fatima 5

\begin{abstract}
Objective: To determine the impact of Kisspeptin on male reproductive axis in a selected urban population. Methods: The cross-sectional study was conducted at the Sindh Institute of Reproductive Medicine in collaboration with Aga Khan University, Karachi, from July, 2017, to February, 2018, and comprised infertile males with abnormal sperm parameters who were placed in Group A and fertile males with normal sperm parameters placed in Group B. Serum samples were estimated for Kisspeptin, follicle stimulating hormone, luteinizing hormone, testosterone and sex hormone-binding globulin using enzyme-linked immunosorbent assay. Data was analysed using SPSS 22.

Results: Of the 313 male subjects, 178(57\%) were in Group A and 135(43\%) in Group B. Median Kisspeptin levels were higher among fertile males compared to infertile males $(p<0.001)$. Mean follicle stimulating hormone, luteinizing hormone and testosterone values were higher among the fertile males $(p<0.001)$. There was significant interaction between follicle stimulating hormone and testosterone $(p<0.1)$.

Conclusion: Fertility in males depended on optimal secretion of Kisspeptin which exert edits effect on hypothalamic pituitary gonadal axis to increase male reproductive hormone production.

Keywords: Kisspeptin, Infertility, Sperm parameters, Obesity. (JPMA 70: 1125; 2020)

DOI: https://doi.org/10.5455/JPMA.12861
\end{abstract}

\section{Introduction}

Infertility can be defined as the inability of a sexually active, non-contracepting couple to achieve spontaneous pregnancy after one year. ${ }^{1}$ It is a global problem that entails serious sexual and social consequences that strain the health sector and society as a whole. ${ }^{2}$ According to Agarwal et al., male factors account for $20-70 \%$ of infertility problems faced by the commonly quoted $15 \%$ of couples worldwide. ${ }^{3}$ This may be due to congenital or acquired urogenital problems, abnormalities, genetic predisposition, immune system factor disorders of the immune system, infections, malignancies and/or endocrine malfunction, but $30 \%$ of the time, male infertility presents idiopathically. 4

Kisspeptin (KP) is one of the two RF-amide peptide hormone produced from the KISS1 gene via the plasma proteolytic cleavage of the gene product. Role of KP as a vital activator of reproductive endocrinological activity can be evidenced by the location of KISS1receptors in hypothalamus, basal ganglia and periventricular area (central nervous system [CNS]) as well as in structures like testis, spermatozoa, ovary and endometrium. KISS1 acts on KISS1 receptors on gonadotrophic-releasing hormone

1,5Department of Biological and Biomedical Sciences, 2Medical Student, Medical College, 3Department of Surgery, Aga Khan University, Karachi, ${ }^{4}$ Department of Physiology, University of Karachi, Pakistan.

Correspondence: Syeda Sadia Fatima. Email: sadia.fatima@aku.edu
$(\mathrm{GnRH})$ neurons and causes release, which increases the firing rate of $\mathrm{GnRH}$ neurons and further increasesLutenizing Hormone (LH) secretion by acting on gonadotrophs. ${ }^{5}$ Studies carried out to determine the role of $K P$ in the regulation of the reproductive axis have documented an increase in oocyte maturity and clinical pregnancy rates of females after intracytoplasmic sperm injection (ICSI), especially in cases of unexplained infertility. ${ }^{6,7}$ Universally, researchers have mainly focussed on females, but recent shift in healthcare dynamics have instigated a fresh look into male infertility and the corresponding factors that influence its extent, severity and prevalence. Serum levels of KP have been investigated in only limited number of studies which don't give the insights of the causative factors of male infertility. ${ }^{8,9}$ The current study was planned to determine the impact of KP on male reproductive axis in a selected urban population, and to bridge the gap by exploring the correlative and causative links between KP and the cascade of released hormones (Figure).

\section{Subjects and Methods}

The cross-sectional study was conducted at the Sindh Institute of Reproductive Medicine (SIRM) in collaboration with Aga Khan University (AKU), Karachi, from July, 2017, to February, 2018. After approval from the AKU ethicsreview board, the sample size was calculated to generate a power of $80 \%$ with $5 \%$ confidence interval $(\mathrm{Cl})^{10}$ while keeping the prevalence of male factor 
infertility at $40 \% .^{3}$ Based on the calculation, infertile and fertile males aged 25-55 years regardless of their ethnic background were enrolled for the study after getting written informed consent from each of them. They were classified as infertile group which comprised males with a sperm concentration $<15 \times 10^{6}$, decreased total sperm motility $<40 \%$ and normal morphology $<4 \%, 11$ and $a$ fertile group which had males who had children and sperm concentration $>15 \times 10^{6}$, total sperm motility $>40 \%$ and normal morphology $>4 \% .{ }^{11}$ Male subjects with pre-existing diabetes and hypertension, and with serious general health status were excluded. Ten millilitreof venous blood from ante-cubital vein was collected from infertile males. Serum obtained by centrifugation of blood was stored at $-70^{\circ} \mathrm{C}$ until further analysis. Serum follicle stimulating hormone (FSH) was determined by using commercially available kit for Human FSH Enzyme Immunoassay (Kit Cat. No KAPD1288 by DIA source Immuno Assays S.A. Belgium). Serum LH estimation was made using commercially available kit for Human LH Enzyme Immunoassay (Kit Cat. No KAPD1289 by DIA source Immuno Assays S.A. Belgium). For Elecsys FSH immunoassay, the inter-assay coefficient of variation (CV) $<6 \%$ and intra-assay $\mathrm{CV}<3 \%$ were used. For Elecsys LH immunoassay the inter-assay CV was $<6 \%$, and intra-assay CV was $<5 \%$. Serum sex hormone-binding globulin (SHBG) estimation was done using commercially available kit for SHBG Enzyme Immunoassay (Kit Cat. No 10222 by Glory Science Co, Ltd USA) following the manufacturer's protocol. Serum KP was measured using KISS1 enzyme-linked immunosorbent assay (ELISA) Kit (Cat.No: YHB1811Hu, Glory BioScience, USA) following the manufacturer's protocol. The analytical sensitivity was $10.16 \mathrm{ng} / \mathrm{L}$ and intra- and inter-assay CVs was less than $10 \%$ and $12 \%$, respectively.

Data was analysed using SPSS 22. Descriptive statistics were computed for categorical variables by computing their frequencies and percentages, assessed by chi-square where expected frequency in each cell was $>5$ and Fisher's exact test where any one cell had frequency $<5$. The distribution of quantitative variables was computed by their means and standard deviations/ median and interquartile range (IQR) depending onthe normality of the data, and assessed by independent $t$ test / Mann Whitney test. Correlation was assessed between quantitative variables by Pearson correlation for normally distributed data, and spearman correlation for non-normally distributed data. Unadjusted and adjusted prevalence ratio (PRs) with their 95\% Cls were reported using simple and multiple Cox regression. All plausible interactions and confounding factors were assessed.

\section{Results}

Of the 313 male subjects, 178(57\%) were infertile and 135(43\%) were fertile. Median KP levels were higher among fertile males compared to infertile males ( $p$ $<0.001$ ). The mean age of the fertile participants was higher, but infertile males had a higher BMI and Body fat percentage $(\mathrm{BF} \%)$ value compared to the fertile group $(p<0.001)$. Mean FSH, LH and testosterone values were higher among fertile males $(p<0.001)$. Median SHBG was higher among fertile males $(p<0.001)$. A strong positive

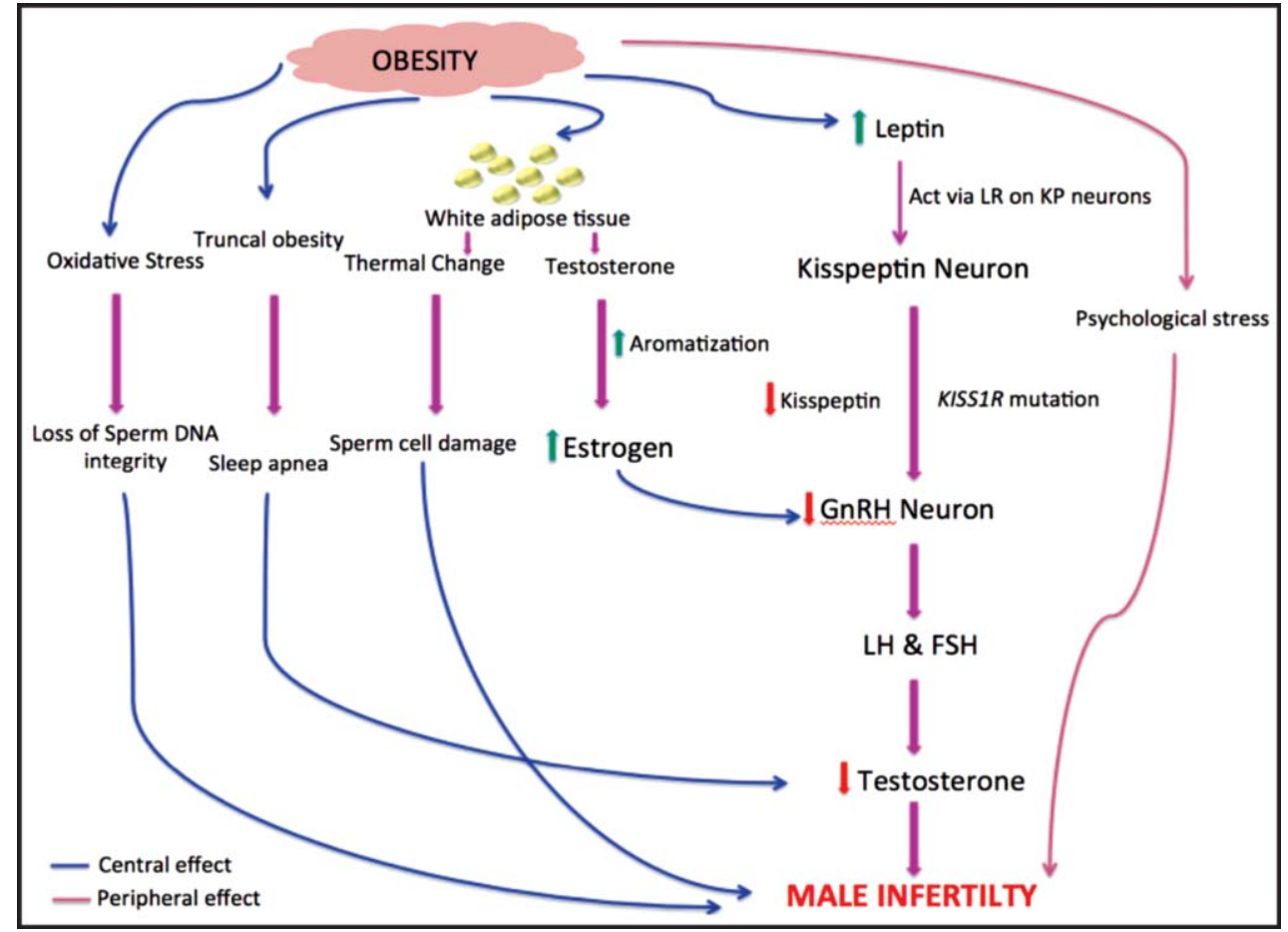

Increased adiposity plays a pivotal role in disturbing the hypothalamic-pituitary-gonadal axis leading to decreased testosterone ultimately causing male infertility.

GnRH: Gonadotropin releasing hormone; KP: Kisspeptin; LR: Leptin receptor; LH: Leutinizing hormone; FSH: Follicular stimulating hormone.

Figure: Possible pathophysiology involved in causing male infertility. 
Table-1: Clinical and biochemical characteristic of fertile and infertile males.

\begin{tabular}{lccc}
\hline Factors & $\begin{array}{c}\text { Infertile ( } \mathbf{n = 1 7 8} \\
\text { Mean } \pm \text { SD }\end{array}$ & $\begin{array}{c}\text { Infertile (n=135) } \\
\text { Mean } \pm \text { SD }\end{array}$ & P value \\
\hline Age (in years) & $33.74 \pm 5.67$ & $37.65 \pm 6.12$ & $<0.001$ \\
BMl (in kg/m²) & $26.67 \pm 3.59$ & $24.76 \pm 3.08$ & $<0.001$ \\
Body Fat (\%) & $34.37 \pm 4.66$ & $32.97 \pm 4.06$ & 0.006 \\
FSH (in mlU/ml) & $3.41 \pm 1.97$ & $6.31 \pm 2.50$ & $<0.001$ \\
LH (in mlU/ml) & $5.45 \pm 2.90$ & $9.96 \pm 2.58$ & $<0.001$ \\
Testosterone (in ng/ml) & $3.35 \pm 1.92$ & $8.16 \pm 1.38$ & $<0.001$ \\
& & & \\
& Median (IQR) & Median (IQR) & \\
SHBG (nmol/L) & $15.44(12.06-18.95)$ & $32.06(25.98-30.71)$ & $<0.001$ \\
Kisspeptin (ng/ml) & $6.25(5.65-6.95)$ & $16.25(15.6-43.75)$ & $<0.001$ \\
& & & \\
& Absolute & Absolute & \\
& count (\%) & count (\%) & \\
Normal weight (18 - $\left.22.9 \mathrm{~kg} / \mathrm{m}^{2}\right)$ & $28(15.7 \%)$ & $41(30.4 \%)$ & $<0.001$ \\
Overweight (23 - $\left.24.9 \mathrm{~kg} / \mathrm{m}^{2}\right)$ & $25(14.0 \%)$ & $27(20.0 \%)$ & \\
Obese $\left(\geq 25 \mathrm{~kg} / \mathrm{m}^{2}\right)$ & $125(70.2 \%)$ & $67(49.6 \%)$ & \\
\hline
\end{tabular}

*Significant at $p$ value $<0.05$

SD: Standard deviation; BMI: Body mass index; FSH: Follicle stimulating hormone; LH: Luteinizing hormone; SHBG: Sex hormone-binding globulin.

correlation was observed between $\mathrm{LH}$ and testosterone $(r=0.954 ; p=0.002)$ and between SHBG and LH (rho=0.933; $\mathrm{p}<0.001)$ (Table-1).

Univariate analysis showed that with every one unit increase in $\mathrm{KP}$, the prevalence of being infertile was decreased by $6.6 \%$. Similarly, with every 1 unit increase in age (year), FSH $(\mathrm{mlU} / \mathrm{ml}), \mathrm{LH}(\mathrm{mlU} / \mathrm{ml})$, testosterone $(\mathrm{ng} / \mathrm{ml})$ and SHBG, the prevalence of being infertile was decreased by $4.7 \%, 20 \%, 15.7 \%, 22.4 \%$ and $6.9 \%$ respectively. Moreover, with every $1 \mathrm{~kg} / \mathrm{m}^{2}$ increase in
BMI, the prevalence of being infertile increased by $6.9 \%$. Likewise, the males who were obese $\left(\geq 25 \mathrm{~kg} / \mathrm{m}^{2}\right)$ were 1.604 times more likely to be infertile compared to those who were of normal weight (Cl:1.065-2.417).

In the final Cox regression model which included KP, FSH and testosterone, it was observed that after adjusting for $\mathrm{FSH}$ and testosterone, with every one unit increase in $\mathrm{KP}$, the prevalence of being infertile decreased by $2.7 \%$. There was significant interaction between $\mathrm{FSH}$ and testosterone $(p<0.1)$. Hence, with every 1 unit rise in serum testosterone level, the FSH led to $4.6 \%$ decrease in infertility (Table-2).

\section{Discussion}

The study observed low serum KP levels with reduced LH, $\mathrm{FSH}$, testosterone, SHBG levels in male infertile subjects. The findings are similar to an earlier study. ${ }^{12}$ Further analysis showed that higher serum KP levels were associated with a significant increase in reproductive hormones, which suggested its crucial role in the central regulation of male reproductive axis and fertility. KP also exerts peripheral effects alongwith its central regulation resulting from its steroid-independent role in intermediating stress-induced suppression of reproductive functions. ${ }^{13}$

The impact of KP on hypothalamo-pituitary gonadal (HPG) axis can further be complemented by the incidence of hypogonadotropic hypogonadism presenting with absent or delayed reproductive function and pubertal maturation, caused by mutations in the gene encoding for a G protein-coupled receptor (GPR54)of KISS1R. This key was further substantiated by a demonstration in which mice lacking functional GPR54 or KISS1 genes were

Table-2: Interface of Kisspeptin (KP), clinical and hormonal profile and the risk of infertility by univariate and multivariate analysis.

\begin{tabular}{|c|c|c|c|c|}
\hline Factors & Unadjusted Prevalence Ratio (95\% CI) & P value & Adjusted Prevalence Ratio (95\% CI) & P value \\
\hline Age (year) & $0.953(0.929-0.978)$ & $<0.001^{*}$ & -- & -- \\
\hline Normal weight & Reference & -- & -- & \\
\hline Overweight & $1.185(0.691-2.032)$ & 0.047 & -- & -- \\
\hline Obese & $1.604(1.065-2.417)$ & 0.002 & -- & -- \\
\hline Body Fat (\%) & $1.031(0.998-1.066)$ & 0.07 & -- & -- \\
\hline \multicolumn{5}{|l|}{ LH (in mlU/ml) } \\
\hline $0.843(0.805-0.882)$ & $<0.001$ & -- & -- & \\
\hline SHBG nmol/L & $0.931(0.912-0.950)$ & $<0.001$ & -- & -- \\
\hline Kisspeptin(ng/ml) & $0.934(0.912-0.957)$ & $<0.001$ & $0.973(0.954-0.993)$ & $0.008^{*}$ \\
\hline $\mathrm{FSH}(\mathrm{mlU} / \mathrm{ml})$ & $0.796(0.740-0.855)$ & $<0.001$ & $1.091(0.957-1.243)$ & 0.193 \\
\hline Testosterone (ng/ml) & $0.776(0.735-0.820)$ & $<0.001$ & $1.011(0.886-1.153)$ & 0.873 \\
\hline FSH* Testosterone & -- & -- & $0.954(0.927-0.983)$ & 0.002 \\
\hline
\end{tabular}

*Significant at $p$ value $<0.05$

\# Significant at $p$ value $<0.1$

FSH: Follicle stimulating hormone;LH: Luteinizing hormone; SHBG: Sex hormone-binding globulin. 
phenocopies of the humans affected. ${ }^{14}$ Jayasena et al. reported that exogenously-administered Kisspeptin-10 bolus even at low doses stimulated gonadotropin release ${ }^{15}$ in males primarily but also in women during the pre-ovulatory phase of the menstrual cycle.

The observation by the current study of increase in FSH and $\mathrm{LH}$ secretion is supported by studies that documented KP as a powerful stimulator of $\mathrm{LH}$ and FSH release, both after intra-cerebral and systemic administration of the peptide. ${ }^{16}$ The increased LH secretion in fertile males with increased KP is supported by Pinilla et al. who reported that KP plays a crucial role in increased LH secretion, and to lesser extent FSH secretion as well. ${ }^{5}$ George et al. further complemented this report by discovering that exogenous KP-10 administration resulted in an increase in LH pulse frequency and secretion, with increased testosterone levels in the hypogonadal men suffering from type 2 diabetes. ${ }^{17} \mathrm{We}$ observed increased concentration of both $\mathrm{LH}$ and $\mathrm{FSH}$ which is contrary to a study which documented greater sensitivity of $\mathrm{LH}$ release to the stimulatory effect of $\mathrm{KP}$ in comparison to $\mathrm{FSH} .{ }^{16}$

Down-streaming the HPG axis, KP potentially increased the serum testosterone levels in normal males which is comparable to Dhillo et al. ${ }^{18}$ In addition, it has also been demonstrated that systemic KP administration in males who are infertile and/or have azoospermia can cause increased testosterone secretion in addition to $\mathrm{LH}$ and FSH. However, chronic increase may lead to testicular atrophy, causing a drop in testosterone levels and an increase, decrease or no change in LH and FSH levels. ${ }^{18}$ We also observed a strong positive correlation between $\mathrm{LH}$ and testosterone. This causal relationship and the reversibility of the levels has been authenticated with a decrease in weight loss. ${ }^{19}$

Obesity alters fertility both centrally and peripherally. The anticipated patho-physiological mechanisms thus explain the multi-factorial relationships involved. Apart from influencing the HPG axis and the aromatisation, truncal obesity also causes hypoxaemia during sleep apnoea, which might disrupt the morning testosterone secretion. ${ }^{20}$ Additionally, there is loss of sperm deoxyribonucleic acid (DNA) integrity caused by the activation of seminal macrophage due to enhanced redox activity in obese men. ${ }^{21}$ Nevertheless the psychological influence can also lead to erectile dysfunctions. ${ }^{22}$ Literature insinuates links between degree of obesity and male fertility by affecting the total testosterone,oestrogen and reduced Sertoli cell functions. ${ }^{23}$ This might be on account of increased white adipose tissue present in obese males. White adipocytes are accountable for the aromatase activity within the adipocytes that converts available testosterone to estradiol, resulting in decreased testosterone level in such individuals. Simultaneously, oestrogens stored in the fat tissues act as a suppressor on the HPG axis. Decreasing the $\mathrm{GnRH}$ release ultimately lowers the secretion of $\mathrm{LH}$ and $\mathrm{FSH}$, leading to diminished gonadal testosterone release Therefore, it is possible that the high BF\% in our subjects could have an indirect effect on testosterone levels modulating the HPG axis. Leptin is an adipokine that regulates body composition and satiety (Figure). In addition, it also stimulates GnRH neurons in the hypothalamus to induce $\mathrm{LH}$ release and subsequent testicular stimulation of testosterone release under normal conditions. ${ }^{24} \mathrm{~A}$ previous study showed a relation of Leptin-KP axis in female infertility; expressed by maximum number of clinical pregnancies in the group that showed strongest relationship between serum Leptin and KP levels. ${ }^{25} \mathrm{GnRH}$ neurons have little or no leptin receptor expression but possess the $\mathrm{KP}$ receptor and KP neurons that express the leptin receptor, thus modulating the $\mathrm{GnRH}$ secretion. However, hypothalamic leptin resistance is common in obesity, leading to a loss of feedback stimulation of testosterone production. 25

After adjusting for covariates FSH and testosterone, chances of becoming infertile increased with every one unit increase in KP. The causative effect between KP levels and the changes in the reproductive status, however, needs to be explored further.The current study is complimentary in nature because majority of studies have focussed on the hypothalamic and pituitary impact of KP administration as opposed to serum hormonal and protein biomarker levels.

\section{Conclusion}

KP plays an important role in male fertility by increasing the production of hormones of the male reproductive axis; namely FSH, LH and testosterone. Absence of negative feedback inhibition of KP by increased testosterone supports its production from peripheral reproductive organs besides central nervous system.

\section{Disclaimer: None.}

\section{Conflict of Interest: None.}

Source of Funding: Department of Biological \& Biomedical Sciences and Research Module Funds, Aga Khan University, Karachi.

\section{References}

1. Rowe PJ, Comhaire FH, Hargreave TB, Mahmoud AMA. WHO manual for the standardized investigation and diagnosis of the infertile male. Cambridge, UK: Cambridge University Press, 2000; pp 102. 
2. Alam F, Khan TA, Rehman R. Stress of infertility: Can the couple cope? J Pak Med Assoc 2018;68:679-80.

3. Agarwal A, Mulgund A, Hamada A, Chyatte MR. A unique view on male infertility around the globe. Reprod Biol Endocrinol 2015;13:37. doi: 10.1186/s12958-015-0032-1.

4. Nieschlag E. Scope and goals of andrology. In: Nieschlag E, Behre HM, Nieschlag S, eds. Andrology: Male Reproductive Health and Dysfunction, 3rd ed. Heidelberg, Germany: Springer, 2010; pp 1-10.

5. Pinilla L, Aguilar E, Dieguez C, Millar RP, Tena-Sempere M. Kisspeptins and reproduction: physiological roles and regulatory mechanisms. Physiol Rev 2012;92:1235-316. doi: 10.1152/physrev.00037.2010.

6. Mumtaz A, Khalid A, Jamil Z, Fatima SS, Arif S, Rehman R. Kisspeptin: A Potential Factor for Unexplained Infertility and Impaired Embryo Implantation. Int J Fertil Steril 2017;11:99-104. doi: 10.22074/ijfs.2017.4957.

7. Jamil Z, Fatima SS, Arif S, Alam F, Rehman R. Kisspeptin and embryo implantation after ICSI. Reprod Biomed Online 2017;34:147-153. doi: 10.1016/j.rbmo.2016.11.004.

8. Agarwal A, Sharma RK, Nallella KP, Thomas AJ Jr, Alvarez JG, Sikka SC. Reactive oxygen species as an independent marker of male factor infertility. Fertil Steril 2006;86:878-85.

9. Mehra BL, Skandhan KP, Prasad BS, Pawankumar G, Singh G, Jaya V. Male infertility rate: a retrospective study. Urologia 2018;85:2224. doi: 10.5301/uj.5000254.

10. Kelsey JL, Whittemore AS, Evans AS, Thompson WD. Methods in observational epidemiology 2nd ed. New York, USA: Oxford University Press, 1996; pp 432.

11. Menkveld R, Wong WY, Lombard CJ, Wetzels AM, Thomas CM, Merkus HM, et al. Semen parameters, including WHO and strict criteria morphology, in a fertile and subfertile population: an effort towards standardization of in-vivo thresholds. Hum Reprod 2001;16:1165-71.

12. Ramzan MH, Ramzan M, Ramzan F, Wahab F, Jelani M, Khan MA, et al. Insight into the serum kisspeptin levels in infertile males. Arch Iran Med 2015;18:12-7. doi: 0151801/AIM.005.

13. Iwasa T, Matsuzaki T, Tungalagsuvd A, Munkhzaya M, Kawami T, Niki $\mathrm{H}$, et al. Hypothalamic Kiss1 and RFRP gene expressions are changed by a high dose of lipopolysaccharide in female rats. Horm Behav 2014;66:309-16. doi: 10.1016/j.yhbeh.2014.06.007.

14. Seminara SB, Messager S, Chatzidaki EE, Thresher RR, Acierno Jr JS, Shagoury JK, et al. The GPR54 gene as a regulator of puberty. Obstet Gynecol Surv 2004;59:351-3.

15. Jayasena CN, Nijher GM, Comninos AN, Abbara A, Januszewki A,
Vaal $M L$, et al. The effects of kisspeptin-10 on reproductive hormone release show sexual dimorphism in humans. J Clin Endocrinol Metab 2011;96:e1963-72. doi: 10.1210/jc.2011-1408.

16. Navarro VM, Castellano JM, Fernández-Fernández R, Tovar S, Roa J, Mayen A, et al. Effects of KiSS-1 peptide, the natural ligand of GPR54, on follicle-stimulating hormone secretion in the rat. Endocrinology 2005;146:1689-97.

17. George JT, Veldhuis JD, Tena-Sempere M, Millar RP, Anderson RA. Exploring the pathophysiology of hypogonadism in men with type 2 diabetes: kisspeptin-10 stimulates serum testosterone and LH secretion in men with type 2 diabetes and mild biochemical hypogonadism. Clin Endocrinol (Oxf) 2013;79:100-4. doi: 10.1111/cen.12103.

18. Dhillo WS, Chaudhri OB, Patterson M, Thompson EL, Murphy KG, Badman MK, et al. Kisspeptin-54 stimulates the hypothalamicpituitary gonadal axis in human males. Obstet Gynecol Surv 2007;62:38-9.

19. Chavarro JE, Toth TL, Wright DL, Meeker JD, Hauser R. Body mass index in relation to semen quality, sperm DNA integrity, and serum reproductive hormone levels among men attending an infertility clinic. Fertil Steril 2010;93:2222-31. doi: 10.1016/j.fertnstert.2009.01.100.

20. Hausman GJ, Barb CR, Lents CA. Leptin and reproductive function Biochimie 2012;94:2075-81. doi: 10.1016/j.biochi.2012.02.022.

21. Zorn B, Vidmar G, Meden-Vrtovec H. Seminal reactive oxygen species as predictors of fertilization, embryo quality and pregnancy rates after conventional in vitro fertilization and intracytoplasmic sperm injection. Int J Androl 2003;26:279-85.

22. Esposito K, Giugliano F, Di Palo C, Giugliano G, Marfella R, D'Andrea $F$, et al. Effect of lifestyle changes on erectile dysfunction in obese men: a randomized controlled trial. JAMA 2004;291:2978-84.

23. Hackett G, Cole N, Bhartia M, Kennedy D, Raju J, Wilkinson P. Testosterone replacement therapy with long-acting testosterone undecanoate improves sexual function and quality-of-life parameters vs. placebo in a population of men with type 2 diabetes. J Sex Med 2013;10:1612-27. doi: 10.1111/jsm.12146.

24. Amjad S, Baig M, Zahid N, Tariq S, Rehman R. Association between leptin, obesity, hormonal interplay and male infertility. Andrologia 2019;51:e13147. doi: 10.1111/and.13147.

25. Rehman R, Jamil Z, Khalid A, Fatima SS. Cross talk between serum Kisspeptin-Leptin during assisted reproduction techniques. Pak J Med Sci 2018;34:342-6. doi: 10.12669/pjms.342.14078. 